\title{
Analisis Perbandingan Model Matrix Factorization dan K-Nearest Neighbor dalam Mesin Rekomendasi Collaborative Berbasis Prediksi Rating
}

\author{
Janny Eka Prayogo ${ }^{1}$, Aries Suharso², Adhi Rizal $^{3}$ \\ ${ }^{1,2,3}$ Program Studi Teknik Informatika, Fakultas Ilmu Komputer, Universitas Singaperbangsa \\ Karawang, Jl. HS. Ronggo Waluyo, Kec. Telukjambe Timur, Karawang, Indonesia, 41361 \\ e-mail: 1jannyeka.16125@student.unsika.ac.id, 2aries.suharso@unsika.ac.id, \\ 3adhi.rizal@unsika.ac.id
}

Submitted Date: October $13^{\text {th }}, 2020$

Revised Date: January $02^{\text {nd }}, 2021$
Reviewed Date: December $30^{\text {th }}, 2020$

Accepted Date: January $04^{\text {th }}, 2021$

\begin{abstract}
Rating is a form of assessment of the likes or dislikes of a user or customer for an item. Where the higher the rating number given, the item is preferred by customers or users. In the recommendation engine, a set of ratings can be predicted and used as an object to generate a recommendation by the Collaborative Filtering method. In the Collaborative Filtering method, there is a rating prediction model, namely the Matrix Factorization and K-Nearest Neighbor models. This study analyzes the comparison of the two prediction models based on the value of Mean Absolute Error (MAE), Root Mean Squared Error (RMSE) and the prediction results generated using the movielens film rating dataset. From the analysis and testing results, it was found that MAE $=0.6371$ and $\mathrm{RMSE}=0.8305$ for the Matrix Factorization model, while MAE $=0.6742$ and RMSE $=0.8863$ for the K-Nearest Neighbor model. The best model is Matrix Factorization because the MAE and RMSE values are lower than the K-Nearest Neighbor model and have the closest predicted rating results from the original rating value.
\end{abstract}

Keywords: Rating; Recommendation Engine; Collaborative Filtering; Matrix Factorization; K-Nearest Neighbor

\begin{abstract}
Abstrak
Rating atau peringkat penilaian merupakan suatu bentuk penilaian suka atau tidak suka dari seorang pengguna atau pelanggan terhadap suatu item. Di mana semakin tinggi angka rating yang diberikan maka item tersebut lebih disukai oleh pelanggan atau pengguna. Di dalam mesin rekomendasi, kumpulan rating dapat diprediksi dan dijadikan sebuah objek untuk menghasilkan sebuah rekomendasi oleh metode Collaborative Filtering. Di dalam metode Collaborative Filtering terdapat model prediksi rating yaitu model Matrix Factorization dan K-Nearest Neighbor. Penelitian ini menganalisis perbandingan dari kedua model prediksi yang didasarkan pada nilai Mean Absolute Error (MAE), Root Mean Squared Error (RMSE) dan hasil prediksi yang dihasilkan dengan menggunakan dataset rating film movielens. Dari hasil analisis dan pengujian, didapat MAE $=0.6371$ dan $\mathrm{RMSE}=0.8305$ untuk model Matrix Factorization, Sedangkan MAE $=0.6742$ dan RMSE $=0,8863$ untuk model $K$-Nearest Neighbor. Model terbaik adalah Matrix Factorization karena nilai MAE dan RMSE yg lebih rendah dari model $K$-Nearest Neighbor dan memiliki hasil prediksi rating yang paling mendekati dari nilai rating aslinya.
\end{abstract}

Kata Kunci: Rating; Mesin Rekomendasi; Collaborative Filtering; Matrix Factorization; K-Nearest Neighbor

\section{Pendahuluan}

Sistem Rekomendasi merupakan suatu sistem yang dapat memberikan sebuah rekomendasi sebuah item melalui penyaringan, pemilihan informasi dengan menggunakan preferensi dari pengguna berupa profil, peringkat, perilaku untuk membantu suatu individu atau komunitas dalam menemukan konten atau item yang menarik yang kemungkinan besar akan dipilih, digunakan atau dibeli. sedangkan Mesin 
Rekomendasi yaitu suatu algoritma terstruktur perhitungan matematika untuk mengidentifikasi dan mempelajari pola pengguna, pola item, dan kaitan antar keduanya untuk memprediksi item yang kemudian akan direkomendasikan (Sorde \& Deshmukh, 2015).

Pada Mesin Rekomendasi memiliki dua metode yang sering digunakan, yaitu content-based filtering dan collaborative filtering (Adellya, Devi, \& Tonara, 2015). Di dalam metode content-based filtering rekomendasi dihasilkan dari pemanfaatan sebuah hubungan atau relasi antar konten sebuah item dan profil pengguna, di mana konten dari sebuah item itu seperti author, genre, dll. Namun dalam metode content-based filtering memiliki sebuah kelemahan di mana apabila user memiliki lebih dari satu prefernsi (suatu hal yang di sukai) maka metode ini tidak mampu melakukan sebuah rekomendasi. Kemudian metode collaborative filtering hadir untuk menutupi kelemahan dari content-based filtering tersebut. Di dalam metode collaboartive filtering, rekomendasi dihasilkan berdasarkan prediksi sebuah rating (peringkat nilai) suatu item dari pengguna sebelumnya yang memiliki preferensi yang mirip.

Pada metode collaborative filtering terdapat dua model prediksi yang sering digunakan untuk memprediksi rating (peringkat nilai) yang kemudian akan menjadi sebuah rekomendasi. Model tersebut adalah model matrix factorization dan k-nearest neighbor. Matrix factorization atau faktorisasi matriks adalah salah satu teknik yang digunakan dalam sistem rekomendasi. Matrix factorization memodelkan interaksi antara pengguna dan item dibalik data historis rating (peringkat nilai) eksplisit dan implisit ( $\mathrm{Li}$ et al., 2019). Matrix factorization mengkarakterkan antara pengguna dan item dengan sebuah vektor dari pola pemberian rating (peringkat nilai) pengguna. nilai keterkaitan yang besar antara pengguna dan item mengarah ke sebuah rekomendasi (Syahrani, Setiawan, \& Suryani, 2015). Sedangkan k-nearest neighbor merupakan suatu bentuk model klasifikasi yang dapat mengklasifikasikan data berdasarkan jarak terdekat. Model KNN ini juga merupakan salah satu pendekatan yang lebih disukai untuk rekomendasi berbasis metode collaborative filtering, karena keuntungan dari classifier ini adalah secara konseptual sangat terkait dengan ide collaborative filtering yaitu: menemukan pengguna yang berpikiran sama (atau barang serupa), pada dasarnya konsep tersebut sama saja seperti mencari neighbor (tetangga) untuk pengguna atau barang tertentu karena pendekatan ini akan menghitung "distance" antara rating (peringkat nilai) item target dengan item lainnya (Amatriain, Jaimes, Oliver, \& Pujol, 2011).

Pada penelitian Sistem Rekomendasi ECommerce Menggunakan K-Nearest Neighbor dalam menentukan top-n Rekomendasi produk untuk setiap pelanggan, menghasilkan Recall sebesar 0,404 pada $\mathrm{K}=100$ menggunakan metode Collaborative Filtering (Prasetya, 2017). Sedangkan pada penelitian sistem rekomendasi artikel berita menggunakan metode $k$-Nearest Neighbor berbasis website menghasilkan prediksi rating (peringkat nilai) dengan nilai RMSE sebesar $14 \%$ atau nilai akurasi sebesar $86 \%$ (Abraham \& Rahayu, 2017). Lalu pada penelitian rekomendasi buku menggunakan Tags dan Latent pada Matrix Factorization menghasilkan Nilai MAE 0,41 (Krishnamurty, Nurjanah, \& Rismala, 2017). Sedangkan pada penelitian sistem rekomendasi ECommerce menggunakan Matrix Factorization, menghasilkan Nilai MAE sebesar 0,0099 pada pembagian $95 \%$ data latih dan $5 \%$ data uji, kemudian menghasilkan nilai MAE sebesar 0,4743 pada $80 \%$ data latih dan $20 \%$ data uji (Syahrani et al., 2015).

Berdasarkan penelitian diatas model Matrix Factorization dan model K-Nearest Neighbor cukup baik untuk memprediksi sebuah peringkat yang kemudian dapat mengarah pada sebuah rekomendasi. Sehingga pada penelitian ini penulis akan berfokus pada analisis perbandingan antara model matrix factorization dan $k$-nearest neighbor berdasarkan nilai Mean Absolute Error (MAE), Root Mean Squared Error (RMSE), dan hasil prediksi terbaik yang dihasilkan.

\section{Metode Penelitian}

Penelitian ini dilakukan dengan beberapa tahapan yang dapat dilihat dari gambar 1 .

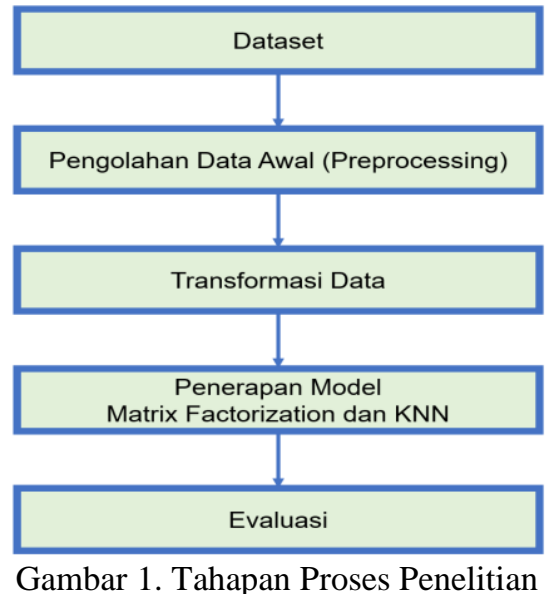

http://openjournal.unpam.ac.id/index.php/informatika 


\subsection{Dataset}

Data yang digunakan pada penelitian ini adalah data rating (peringkat nilai) pada dataset movielens yang didapat dari Grouplens Researcher https://grouplens.org/datasets/movielens/. Di mana terdapat data 100,000 rating oleh 610 user terhadap 9742 film.

\subsection{Pengolahan Data Awal (Preprocessing)}

Data rating (peringkat nilai) yang diperoleh belum bisa langsung diolah begitu saja karena data tersebut masih belum memiliki arti yang jelas (Unimportant Attribute and Noisy), sehingga harus dilakukan sebuah pengolahan data awal terlebih dahulu sebelum diproses pada tahap selanjutnya (Alasadi \& Bhaya, 2017). Pada tahapan ini memiliki sub-tahapan yang dapat dilihat pada gambar 2.

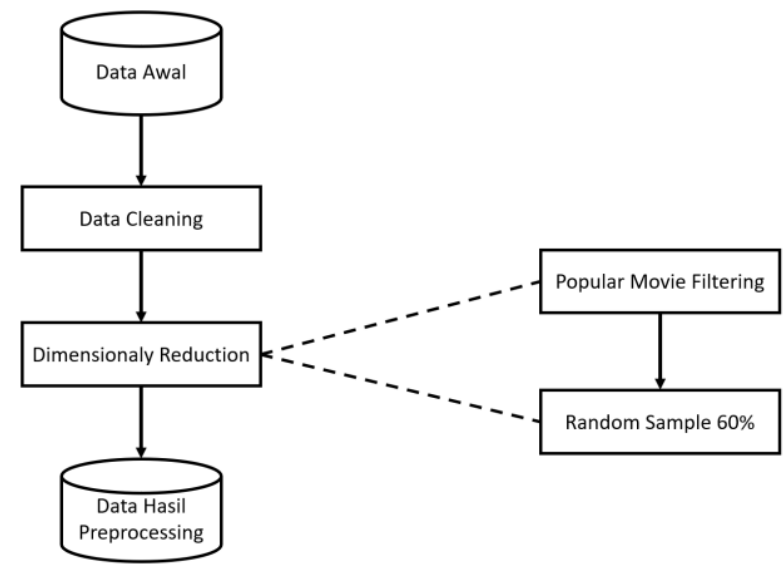

Gambar 2. Tahapan Preprocessing Data

\section{Data Cleaning}

Pada tahapan ini akan dilakukan penghapusan beberapa atribut data yang tidak diperlukan dalam penelitian karena data tersebut dapat mengganggu hasil prediksi.

\section{Dimensionaly Reduction}

Dimensionaly Reduction bertujuan untuk menghindari pola yang noisy dan menghindari "Memory Error" atau kesalahan memori akibat proses komputasi terlalu banyak memakan memori karena kumpulan data yang sangat besar. Pada tahapan ini dilakukan penyaringan film populer berdasarkan rating (peringkat nilai) yang diperoleh sebanyak lebih dari sama dengan 50 rating (peringkat nilai).

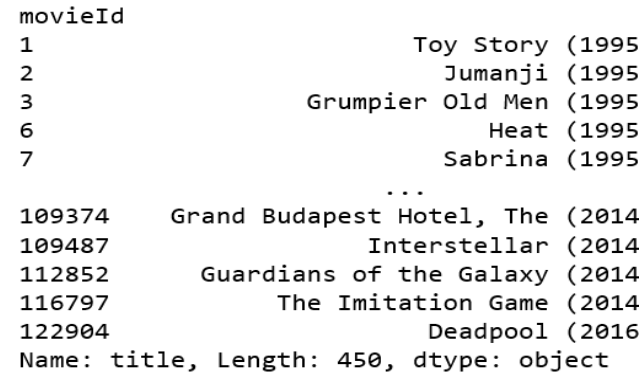

\section{Gambar 3. Popular Movie Filtering}

Gambar 3 menunjukkan bahwa hasil penyaringan film populer memangkas total film yang sebelumnya berjumlah 942 film menjadi 450 film dan mengurangi dimensi data yang sebelumnya 100836 x 3 menjadi 41360 x 3. kemudian dataset akan direduksi kembali dengan cara diambil sebanyak $60 \%$ data sampel.

\begin{tabular}{rrrr} 
& userld & movield & rating \\
\hline $\mathbf{8 1 0 5 5}$ & 513 & 260 & 5.0 \\
$\mathbf{5 5 4 1 4}$ & 368 & 161 & 4.0 \\
$\mathbf{7 1 7 2 5}$ & 462 & 2959 & 3.5 \\
$\mathbf{7 8 0 0 8}$ & 484 & 1258 & 3.5 \\
$\mathbf{1 1 7 7 0}$ & 72 & 296 & 4.5 \\
$\ldots$ & $\ldots$ & $\ldots$ & $\ldots$ \\
$\mathbf{1 8 8 0 1}$ & 121 & 288 & 4.0 \\
$\mathbf{9 2 5 0}$ & 63 & 2683 & 3.0 \\
$\mathbf{1 0 2 1 5}$ & 66 & 3911 & 4.0 \\
$\mathbf{5 4 4 0 7}$ & 357 & 5989 & 4.5 \\
$\mathbf{9 8 7 3 7}$ & 608 & 364 & 3.5 \\
$\mathbf{2 4 8 1 6}$ rows $\times 3$ columns &
\end{tabular}

Gambar 3. Hasil Random Sample 60\%

Pada gambar 4 menjelaskan bahwa reduksi data dengan mengambil sampel data sebanyak $60 \%$ dapat mereduksi dimensi dataset yang sebelumnya 41360 x 3 menjadi 24816 x 3. Hal ini cukup untuk menghindari "Memory Error" pada saat proses prediksi.

\subsection{Transformasi Data}

Transformasi Data yaitu melakukan pengubahan bentuk data menjadi sparse matrix dengan bentuk $m \times n$ array. Di mana $m$ adalah id film dan $n$ adalah id users dan value dari matriks adalah rating (peringkat nilai). Untuk mengubah bentuk dataframe ratings, akan digunakan sebuah fungsi pivot untuk mengubah bentuk data kedalam format yang lebar di mana film sebagai baris dan users sebagai kolom. Hal ini perlu dilakukan agar data dapat dikonsumsi oleh model untuk proses prediksi. 


\begin{tabular}{rrrrrrrrrrrrrrrrrrrrrrrrr}
$\begin{array}{r}\text { userld } \\
\text { movield }\end{array}$ & 1 & $\mathbf{2}$ & $\mathbf{3}$ & $\mathbf{4}$ & $\mathbf{5}$ & $\mathbf{6}$ & $\mathbf{7}$ & $\mathbf{8}$ & $\mathbf{9}$ & $\mathbf{1 0}$ & $\ldots$ & 601 & 602 & 603 & 604 & 605 & 606 & 607 & 608 & 609 & 610 \\
\hline 1 & 4.0 & 0.0 & 0.0 & 0.0 & 4.0 & 0.0 & 4.5 & 0.0 & 0.0 & 0.0 & $\ldots$ & 4.0 & 0.0 & 4.0 & 3.0 & 4.0 & 2.5 & 4.0 & 2.5 & 3.0 & 5.0 \\
2 & 0.0 & 0.0 & 0.0 & 0.0 & 0.0 & 4.0 & 0.0 & 4.0 & 0.0 & 0.0 & $\ldots$ & 0.0 & 4.0 & 0.0 & 5.0 & 3.5 & 0.0 & 0.0 & 2.0 & 0.0 & 0.0 \\
3 & 4.0 & 0.0 & 0.0 & 0.0 & 0.0 & 5.0 & 0.0 & 0.0 & 0.0 & 0.0 & $\ldots$ & 0.0 & 0.0 & 0.0 & 0.0 & 0.0 & 0.0 & 0.0 & 2.0 & 0.0 & 0.0 \\
6 & 4.0 & 0.0 & 0.0 & 0.0 & 0.0 & 4.0 & 0.0 & 0.0 & 0.0 & 0.0 & $\ldots$ & 0.0 & 3.0 & 4.0 & 3.0 & 0.0 & 0.0 & 0.0 & 0.0 & 0.0 & 5.0 \\
7 & 0.0 & 0.0 & 0.0 & 0.0 & 0.0 & 4.0 & 0.0 & 0.0 & 0.0 & 0.0 & $\ldots$ & 0.0 & 0.0 & 0.0 & 0.0 & 0.0 & 2.5 & 0.0 & 0.0 & 0.0 & 0.0 \\
109374 & 0.0 & 0.0 & 0.0 & 0.0 & 0.0 & 0.0 & 0.0 & 0.0 & 0.0 & 0.5 & $\ldots$ & 0.0 & 0.0 & 0.0 & 0.0 & 0.0 & 0.0 & 0.0 & 0.0 & 0.0 & 4.5 \\
109487 & 0.0 & 3.0 & 0.0 & 0.0 & 0.0 & 0.0 & 0.0 & 0.0 & 0.0 & 0.5 & $\ldots$ & 5.0 & 0.0 & 0.0 & 0.0 & 0.0 & 0.0 & 0.0 & 0.0 & 0.0 & 3.5 \\
112852 & 0.0 & 0.0 & 0.0 & 0.0 & 0.0 & 0.0 & 0.0 & 0.0 & 0.0 & 0.0 & $\ldots$ & 4.0 & 0.0 & 0.0 & 0.0 & 0.0 & 0.0 & 0.0 & 0.0 & 0.0 & 4.5 \\
116797 & 0.0 & 0.0 & 0.0 & 0.0 & 0.0 & 0.0 & 0.0 & 0.0 & 0.0 & 0.0 & $\ldots$ & 4.0 & 0.0 & 0.0 & 0.0 & 0.0 & 0.0 & 0.0 & 0.0 & 0.0 & 0.0 \\
122904 & 0.0 & 0.0 & 0.0 & 0.0 & 0.0 & 0.0 & 0.0 & 0.0 & 0.0 & 0.0 & $\ldots$ & 0.0 & 0.0 & 0.0 & 0.0 & 0.0 & 0.0 & 0.0 & 0.0 & 0.0 & 3.0
\end{tabular}

450 rows $\times 606$ columns

Gambar 4. Bentuk Matriks Rating (peringkat nilai)

\subsection{Penerapan Model Matrix Factorization}

Di dalam Matrix Factorization prediksi rating (peringkat nilai) menggunakan algoritma SVD (Singular Value Decomposition). untuk menerapkan SVD dalam domain Collaborative Filtering memerlukan sebuah pemfaktoran matriks peringkat item-pengguna (Bokde, Girase, \& Mukhopadhyay, 2015).

Untuk prediksi $r_{u i}$ ditetapkan sebagai:

$$
\hat{r}_{u i}=\mu+b_{u}+b_{i}+q_{i}^{T} p_{u}
$$

Jika pengguna $u$ tidak diketahui, maka bias $b_{u}$ dan faktor $p_{u}$ diasumsikan nol, hal yang sama berlaku untuk item $i$ dengan $b_{i}$ dan $q_{i}$.

Untuk estimasi semua yang tidak diketahui, sistem meminimalkan kesalahan kuadrat yang diatur oleh berikut ini:

$$
\begin{gathered}
\sum_{r_{u i} \in R_{\text {train }}}\left(r_{u i}-\hat{r}_{u i}\right)^{2}+\lambda\left(b_{i}^{2}+b_{u}^{2}+\left\|q_{i}\right\|^{2}\right. \\
\left.+\left\|p_{u}\right\|^{2}\right)
\end{gathered}
$$

Dan untuk mempelajari vektor faktor $\left(p_{u}\right.$ dan $q_{i}$ ), sistem menimalisir kesalahan kuadrat yang diatur pada set rating (peringkat nilai) yang diketahui sebagai:

$$
\begin{array}{r}
\min _{q^{*}, p^{*}} \sum_{\substack{(u, i) \in K \\
+\lambda\left(\left\|q_{i}\right\|^{2}+\left\|p_{u}\right\|^{2}\right)}}\left(r_{u i}-q_{i}^{T} p_{u}\right)^{2} \\
\end{array}
$$

Disini, K adalah himpunan pasangan $(u, i)$, dan $\mathrm{p}$ diketahui sebagai himpunan training set. Sistem mempelajari model dengan menyesuaikan rating (peringkat nilai) yang diamati sebelumnya.
Tujuannya adalah untuk menggeneralisasi rating (peringkat nilai) sebelumnya dengan cara memprediksi rating (peringkat nilai) yang tidak diketahui untuk kedepannya. Konstanta $\lambda$ mengontrol tingkat regulasi dan biasanya ditentukan oleh cross-validation.

\subsection{Penerapan Model K-Nearest Neighbor}

Dalam prediksi oleh model K-Nearest Neighbor prediksi rating (peringkat nilai) yang diberikan pengguna kepada item dirumuskan sebagai berikut:

$$
\hat{r}_{u i}=\frac{\sum_{j \in N_{u}^{k}(i)} \operatorname{sim}(i, j) \cdot r_{u j}}{\sum_{j \in N_{u}^{k}(i)} \operatorname{sim}(i, j)}
$$

Dengan $\hat{r}_{u i}$ adalah estimasi rating (peringkat nilai) pengguna $\mathrm{u}$ terhadap item $\mathrm{I}$, $\sum_{j \in N_{u}^{k}(i)} \quad$ adalah $k$ tertangga terdekat dari item i yang telah dirating oleh pengguna $\mathrm{u}, \operatorname{sim}(i, j)$ adalah nilai kemiripan antara item $i$ dan item $j$ dan $r_{u j}$ adalah rating sebenarnya dari pengguna $\mathrm{u}$ terhadap item j (Cui, 2017).

\subsection{Evaluasi}

Pada tahap ini akan dilakukan komparasi antara model matrix factorization dan $k$-nearest neighbor berdasarkan nilai Mean Absolute Error (MAE), Root Mean Squared Error (RMSE), dan hasil prediksi yang dihasilkan.

\section{Hasil dan Pembahasan}

Dataset yang telah ditransformasikan kemudian akan diolah dan diprediksi oleh kedua model, proses prediksi akan dilakukan dengan menentukan parameter pada tiap model lalu diuji dengan 5-Fold Cross Validation, yang kemudian 
akan dilakukan Tuning Parameter untuk menghasilkan parameter dengan hasil prediksi terbaik pada tiap model lalu membandingkannya.

\subsection{Pengujian Model K-Nearest Neighbor}

Pengujian pada model K-Nearest Neighbor tahap pertama yaitu menentukan jumlah $\mathrm{K}$ tetangga, lalu tiap $\mathrm{K}$ akan diuji menggunakan 5Fold Cros Validation. Jumlah K yang akan diuji adalah $\mathrm{K}=15, \mathrm{~K}=20, \mathrm{~K}=25, \mathrm{~K}=30, \mathrm{~K}=40, \mathrm{~K}=50$ dan $\mathrm{K}=60$.
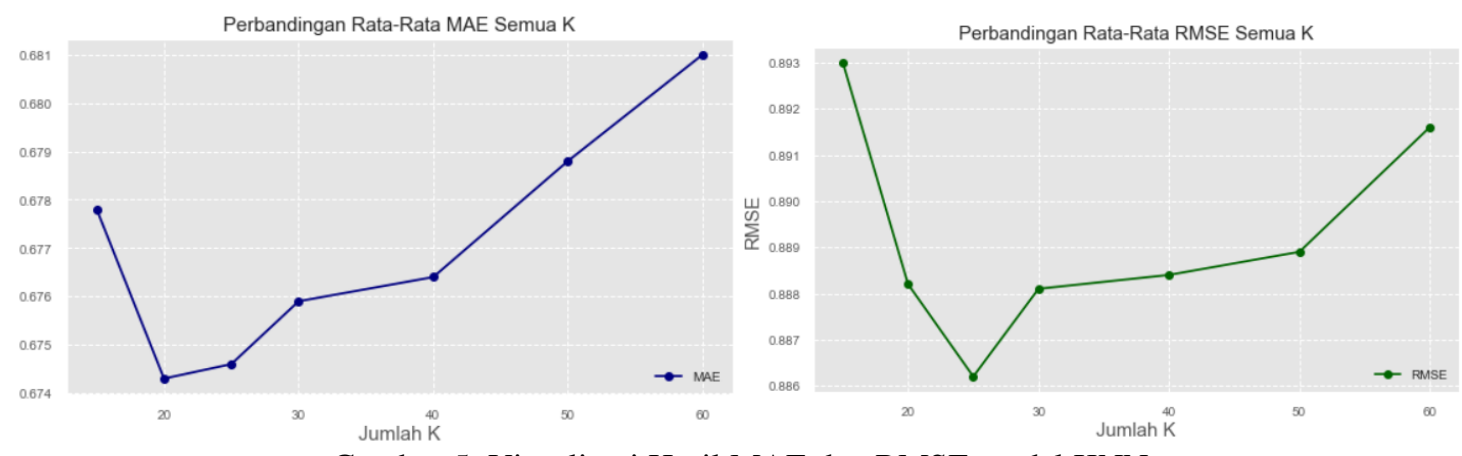

Gambar 5. Visualisasi Hasil MAE dan RMSE model KNN

\section{Tuning Parameter}

Tuning parameter digunakan untuk mencari tahu kombinasi parameter mana yang mengahasilkan akurasi terbaik.

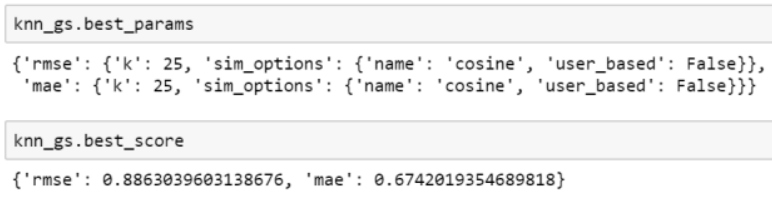

Gambar 6. Hasil Tuning Parameter KNN

Berdasarkan gambar 6 diatas dapat dilihat bahwa hasil tuning parameter menunjukkan parameter terbaik untuk model K-Nearest Neighbor adalah dengan $\mathrm{K}=25$, parameter tersebut menghasilkan nilai MAE sebesar 0,6742 dan RMSE sebesar 0,8863 .

\section{Hasil Prediksi}

Berdasarkan Gambar 4 nilai rating yang kosong akan diisi dengan prediksi estimasi rating oleh model $K N N$. Dan untuk memeriksa ketepatan prediksi akan mencoba melihat hasil prediksi terhadap nilai rating yang sudah diberikan (tidak kosong). Tahap pertama dalam penelitian hasil prediksi ini akan melakukan percobaan prediksi
Tabel 1. Hasil MAE dan RMSE 5-Fold Cross

Validation Model K-Nearest Neighbor

\begin{tabular}{|c|c|c|}
\hline K & MAE & RMSE \\
\hline 15 & 0,6771 & 0,8916 \\
\hline 20 & $\mathbf{0 , 6 7 4 8}$ & 0,8888 \\
\hline 25 & 0,6750 & $\mathbf{0 , 8 8 7 6}$ \\
\hline 30 & 0,6760 & 0,8888 \\
\hline 40 & 0,6775 & 0,8891 \\
\hline 50 & 0,6791 & 0,8904 \\
\hline 60 & 0,6801 & 0,8905 \\
\hline
\end{tabular}

Keterangan: *Cetak tebal menunjukkan angka MAE dan RMSE terendah (semakin rendah semakin baik)

estimasi rating yang kosong pada 10 kolom matriks rating untuk movieId $=1$ dan movieId $=16$.

Tabel 2. Hasil Prediksi Rating Kosong oleh KNN

\begin{tabular}{|c|c|c|}
\hline movieId & userId & Prediksi Rating \\
\hline \multirow{4}{*}{1} & 2 & 3,9000 \\
\cline { 2 - 3 } & 3 & 0,7498 \\
\cline { 2 - 3 } & 4 & 3,6806 \\
\cline { 2 - 3 } & 6 & 4,1599 \\
\hline \multirow{4}{*}{1} & 8 & 3,7607 \\
\cline { 2 - 3 } & 9 & $\mathbf{4 , 3 1 2 5}$ \\
\cline { 2 - 3 } & 10 & 3,2797 \\
\hline \multirow{4}{*}{16} & 1 & $\mathbf{4 , 5 6 0 0}$ \\
\cline { 2 - 3 } & 2 & 3,9020 \\
\cline { 2 - 3 } & 3 & 0,7519 \\
\cline { 2 - 3 } & 4 & 3,2402 \\
\cline { 2 - 3 } & 5 & 3,6000 \\
\cline { 2 - 3 } & 7 & 3,9185 \\
\cline { 2 - 3 } & 9 & 3,8000 \\
\hline
\end{tabular}

Keterangan: *Cetak tebal menunjukkan merupakan hasil prediksi terbesar

Berdasarkan hasil estimasi terbesar, movield $=1$ kemungkinan akan direkomendasikan ke $u$ serId $=9$ dan movieId $=16$ kemungkinan akan direkomendasikan ke $u s e r I d=1$. 
Tabel 3. Hasil Prediksi Nilai Rating Asli oleh KNN

\begin{tabular}{|c|c|c|c|}
\hline movieId & userId & $\begin{array}{c}\text { Rating } \\
\text { Asli }\end{array}$ & $\begin{array}{c}\text { Rating } \\
\text { Prediksi }\end{array}$ \\
\hline \multirow{3}{*}{1} & 1 & 4 & 4,6790 \\
\cline { 2 - 4 } & 5 & 4 & 3,7602 \\
\cline { 2 - 4 } & 7 & 4,5 & 3,8412 \\
\hline 16 & 6 & 4 & 3,8405 \\
\hline
\end{tabular}

Berdasarkan Tabel 3 hasil prediksi estimasi rating oleh model $K N N$ sedikit agak mendekati dari nilai rating aslinya.

\subsection{Pengujian Model Matrix Factorization}

Pada pengujian Matrix Factorization ini akan dilakukan pengujian dengan jumlah $\mathrm{K}$ latent factor 50, 100, 150, 200 dan 250, yang akan di uji dengan iterasi 20, 25, 55, 100 dan menggunakan learning rate 0,005. Lalu akan dilakukan 5-Fold Cross Validation untuk pengujiannya.

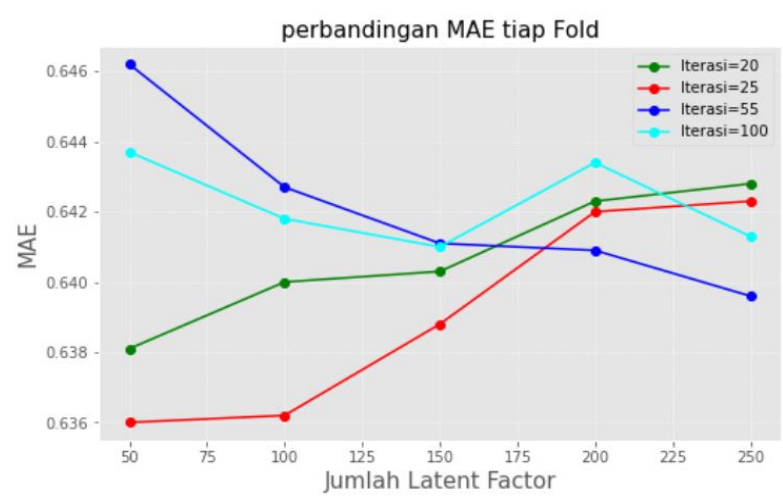

Tabel 4. Hasil MAE dan RMSE 5-Fold Cross

Validation Model Matrix Factorization

\begin{tabular}{|c|c|c|c|}
\hline Iterasi & $\begin{array}{c}\text { Jumlah K } \\
\text { Latent Factor }\end{array}$ & MAE & RMSE \\
\hline \multirow{5}{*}{20} & 50 & 0,6381 & 0,8356 \\
\hline & 100 & 0,6400 & 0,8374 \\
\hline & 150 & 0,6403 & 0,8385 \\
\hline & 200 & 0,6423 & 0,8387 \\
\hline & 250 & 0,6428 & 0,8422 \\
\hline \multirow{5}{*}{25} & 50 & 0,6360 & 0,8349 \\
\hline & 100 & 0,6362 & $\mathbf{0 , 8 3 3 1}$ \\
\hline & 150 & 0,6388 & 0,8371 \\
\hline & 200 & 0,6420 & 0,8394 \\
\hline & 250 & 0,6432 & 0,8404 \\
\hline \multirow{5}{*}{55} & 50 & 0,6462 & 0,8492 \\
\hline & 100 & 0,6418 & 0,8436 \\
\hline & 150 & 0,6421 & 0,8424 \\
\hline & 200 & 0,6434 & 0,8410 \\
\hline & 250 & 0,6413 & 0,8368 \\
\hline \multirow{5}{*}{100} & 50 & 0,6437 & 0,8453 \\
\hline & 100 & 0,6418 & 0,8422 \\
\hline & 150 & 0,6421 & 0,8415 \\
\hline & 200 & 0,6434 & 0,8432 \\
\hline & 250 & 0,6413 & 0,8411 \\
\hline
\end{tabular}

Keterangan: *Cetak tebal menunjukkan angka MAE dan RMSE terendah (semakin rendah semakin baik)

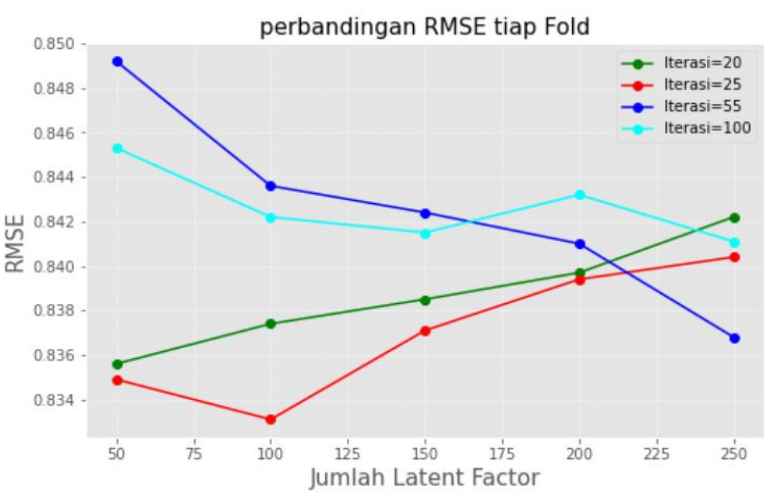

Gambar 7. Visualisasi hasi MAE dan RMSE model MF

\section{Tuning Parameter}

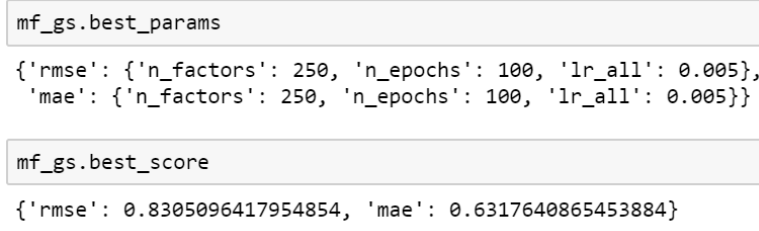

Gambar 8. Contoh Keterangan Gambar

Berdasarkan gambar 8 diatas dapat dilihat bahwa hasil tuning parameter menunjukkan parameter terbaik untuk model Matrix Factorization adalah dengan jumlah latent factor $=$
250 dan iterasi $=100$ yang menghasilkan nilai MAE sebesar 0,6317 dan RMSE sebesar 0,8305.

2. Hasil Prediksi

Tabel 5. Hasil Prediksi Rating Kosong oleh MF

\begin{tabular}{|c|c|c|}
\hline movieId & userId & Prediksi Rating \\
\hline \multirow{4}{*}{1} & 2 & 3,5549 \\
\cline { 2 - 3 } & 3 & 2,1769 \\
\cline { 2 - 3 } & 4 & 3,7144 \\
\cline { 2 - 3 } & 6 & 4,2169 \\
\cline { 2 - 3 } & 8 & $\mathbf{4 , 4 5 5 7}$ \\
\cline { 2 - 3 } & 9 & 4,2981 \\
\cline { 2 - 3 } & 10 & 3,4448 \\
\hline 16 & 1 & $\mathbf{4 , 6 2 7 4}$ \\
\hline
\end{tabular}




\begin{tabular}{|c|c|c|}
\hline movieId & userId & Prediksi Rating \\
\hline \multirow{4}{*}{} & 2 & 4,0018 \\
\cline { 2 - 3 } & 3 & 2,8481 \\
\cline { 2 - 3 } & 4 & 3,0870 \\
\cline { 2 - 3 } & 5 & 3,8254 \\
\cline { 2 - 3 } & 7 & 3,4486 \\
\cline { 2 - 3 } & 8 & 3,5941 \\
\cline { 2 - 3 } & 9 & 4,2667 \\
\hline
\end{tabular}

Keterangan: *Cetak tebal merupakan hasil prediksi terbesar.

berdasarkan hasil estimasi prediksi rating terbesar, movieId $=1$ kemungkinan akan direkomendasikan kepada userId $=8$ dan movieId $=16$ kemungkinan akan direkomendasikan kepada userId $=1$.

Tabel 6. Hasil Prediksi Nilai Rating Asli oleh MF

\begin{tabular}{|c|c|c|c|}
\hline movieId & userId & $\begin{array}{c}\text { Rating } \\
\text { Asli }\end{array}$ & $\begin{array}{c}\text { Rating } \\
\text { Prediksi }\end{array}$ \\
\hline \multirow{3}{*}{1} & 1 & 4 & 4,1655 \\
\cline { 2 - 4 } & 5 & 4 & 3,9348 \\
\cline { 2 - 4 } & 7 & 4,5 & 4,3690 \\
\hline 16 & 6 & 4 & 3,8009 \\
\hline
\end{tabular}

Berdasarkan Tabel 6 hasil prediksi estimasi rating oleh model Matrix Factorization hampir mendekati dari nilai rating aslinya.

\subsection{Analisis Nilai MAE dan RMSE Kedua Model}

Dari beberapa pengujian yang telah dilakukan diatas, diambil hasil pengujian terbaik untuk setiap tuning parameter. Dari hasil tersebut kemudian akan dibandingkan nilai MAE dan RMSE yang diperoleh model Matrix Factorization dan model K-Nearest Neighbor. Berikut merupakan data pengujian rekomendasi dengan model Matrix Factorization dan $K$-Nearest Neighbor berdasarkan MAE dan RMSE.

Tabel 7. Perbandingan MAE dan RMSE Model KNN dan MF

\begin{tabular}{|c|c|c|c|}
\hline Model & $\begin{array}{c}\text { Parameter } \\
\text { Terbaik }\end{array}$ & MAE & EMSE \\
\hline $\begin{array}{c}\text { K-Nearest } \\
\text { Neighbor }\end{array}$ & K=25 & 0,6742 & 0,8863 \\
\hline $\begin{array}{c}\text { Matrix } \\
\text { Factorization }\end{array}$ & $\begin{array}{c}\text { Latent Factor } \\
=250 \\
\text { Iterasi }=100 \\
\text { Learning Rate } \\
=0,005\end{array}$ & 0,6317 & 0,8305 \\
\hline
\end{tabular}

Nilai MAE dan RMSE dari model Matrix Factorization lebih baik, hal ini disebabkan karena pada model Matrix Factorization terdapat algoritma Singular Value Decomposition (SVD) di mana algoritma ini akan mereduksi matriks rating $R$ ' menjadi beberapa rating kecil dan kemudian dikaitkan hasil perkalian matriks $\mathrm{U}$ (m x latent) dan $\mathrm{V}$ (n x latent) untuk menghasilkan estimasi rating dan memiliki prosedur Stochastic Gradient Descent sebagai pengoptimalan value hasil perkalian dan melakukan iterasi pada setiap rating estimasi terhadap rating asli untuk mendapatkan nilai error minimum.

Dari hasil pengujian yang berada pada Tabel 7 dapat diambil kesimpulan sebagai berikut: Semakin banyak jumlah latent factor membuat nilai MAE dan RMSE meningkat, hal ini disebabkan semakin banyak jumlah latent factor semakin besar juga dimensi matriks $\mathrm{U}$ dan $\mathrm{V}$ di mana perkalian antara dua matriks tersebut akan menghasilkan nilai yang besar, sehingga nilainya jauh dari matriks $\mathrm{R}$ (matriks yang diharapkan) dan nilai rating prediksi akan semakin jauh dari rating yang diharapkan. Namun untuk menghindari Overfitting (prediksi model hanya bagus pada data tertentu, namun tidak bagus di data yang lain) fungsi GridSearchCV() memilih latent factor sebanyak 250

Sedangkan pada model K-Nearest Neighbor matriks rating (R') akan dihitung dengan mencari nilai kemiripan antar film oleh algoritma Cosine Similiarity dan mengkelompokkan estimasi rating terdekat sesuai dengan $\mathrm{K}$ yang ditentukan dan mengembalikan nilai estimasi rating yang terbaik, nilai MAE dan RMSE bisa kemungkinan dipengaruhi oleh jumlah data training-nya, karena semakin besar jumlah data training makan nilai kemiripan antar item semakin besar, sehingga hasil prediksi akan mendekati nilai sebenarnya, dan membuat nilai MAE dan RMSE menjadi mengecil. Jadi banyaknya prosedur yang dilakukan yang dimiliki pada setiap model dapat mempengaruhi hasil RMSE dan MAE. Dalam kasus ini untuk efektivitas waktu model $K$-Nearest Neighbor yang menjadi terbaik karena prosedur dalam memprediksi estimasi rating tidak sebanyak model Matrix Factorization namun untuk nilai MAE dan RMSE model Matrix Factorization menjadi yang terbaik. 


\subsection{Analisis Hasil Prediksi Rating}

Tabel 8. Perbandingan Prediksi Rating terhadap Rating Asli Kosong oleh Model KNN dan MF

\begin{tabular}{|c|c|c|c|c|}
\hline \multirow{3}{*}{ movieId } & \multirow{2}{*}{ userId } & \multirow{2}{*}{$\begin{array}{c}\text { Rating } \\
\text { Asli }\end{array}$} & \multicolumn{2}{|c|}{$\begin{array}{c}\text { Hasil Rating } \\
\text { Prediksi }\end{array}$} \\
\cline { 3 - 5 } & & & KNN & MF \\
\hline \multirow{4}{*}{1} & 2 & 0 & 3,9000 & 3,5549 \\
\cline { 2 - 5 } & 3 & 0 & 0,7598 & 2,1769 \\
\cline { 2 - 5 } & 4 & 0 & 3,6806 & 3,7144 \\
\cline { 2 - 5 } & 6 & 0 & 4,1599 & 4,2169 \\
\cline { 2 - 5 } & 8 & 0 & 3,7607 & $\mathbf{4 , 4 5 5 7}$ \\
\cline { 2 - 5 } & 9 & 0 & $\mathbf{4 , 3 1 2 5}$ & 4,2981 \\
\cline { 2 - 5 } & 10 & 0 & 3,2797 & 3,4448 \\
\hline \multirow{4}{*}{16} & 1 & 0 & $\mathbf{4 , 5 6 0 0}$ & $\mathbf{4 , 6 2 7 4}$ \\
\cline { 2 - 5 } & 2 & 0 & 3,9020 & 4,0018 \\
\cline { 2 - 5 } & 3 & 0 & 0,7519 & 2,8481 \\
\cline { 2 - 5 } & 4 & 0 & 3,2402 & 3,0870 \\
\cline { 2 - 5 } & 5 & 0 & 3,6000 & 3,8254 \\
\cline { 2 - 5 } & 8 & 0 & 3,9185 & 3,4486 \\
\cline { 2 - 5 } & 9 & 0 & 3,8000 & 3,5941 \\
\hline
\end{tabular}

Tabel 9. Perbandingan Prediksi Rating terhadap Rating Asli Bernilai oleh Model KNN dan MF

\begin{tabular}{|c|c|c|c|c|}
\hline \multirow{2}{*}{ movieId } & \multirow{2}{*}{ userId } & \multirow{2}{*}{$\begin{array}{c}\text { Rating } \\
\text { Asli }\end{array}$} & \multicolumn{2}{|c|}{$\begin{array}{c}\text { Hasil Rating } \\
\text { Prediksi }\end{array}$} \\
\cline { 4 - 5 } & & & KNN & MF \\
\hline \multirow{3}{*}{1} & 1 & 4 & 4,6790 & 4,1655 \\
\cline { 3 - 5 } & 5 & 4 & 3,7602 & 3,9348 \\
\cline { 2 - 5 } & 7 & 4,5 & 3,8412 & 4,3690 \\
\hline 16 & 7 & 4 & 3,8405 & 3,9009 \\
\hline
\end{tabular}

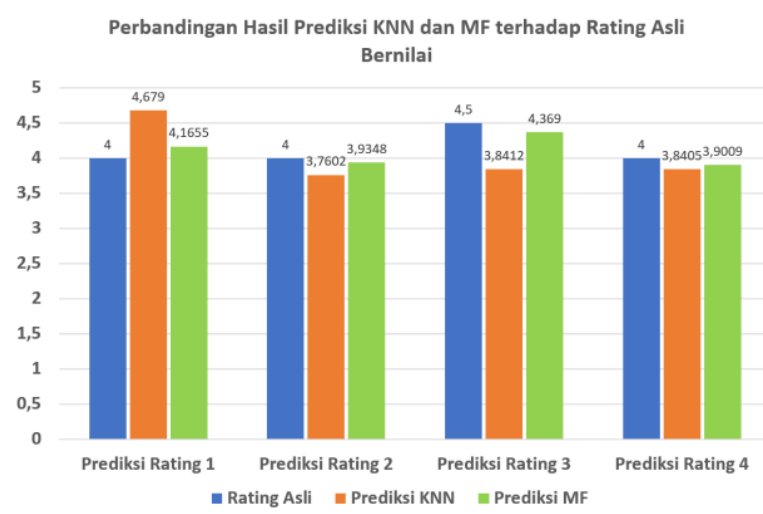

Gambar 9. Visualisasi Prediksi Model terhadap Rating Asli Bernilai

Kedua model berhasil memprediksi estimasi rating terhadap rating asli kosong (nol) dan rating asli yang bernilai. Pada prediksi rating asli kosong (nol), hasil terbesar digunakan untuk mengetahui kemungkinan rekomendasi yang dihasilkan pada setiap model, sedangkan pada prediksi rating asli yang bernilai, digunakan untuk mengetahui seberapa akurat hasil prediksi yang dihasilkan oleh kedua model.
Berdasarkan hasil prediksi terbesar oleh kedua model pada Tabel 8, dapat diketahui bahwa kedua model merekomendasi film dengan label Movield 1 kepada user yang berbeda dan merekomendasi film dengan label MovieId 16 kepada user yang sama. Lalu berdasarkan tabel 9 dan Gambar 9, dapat diketahui bahwa prediksi rating oleh model Matrix Factorization lebih mendekati nilai rating aslinya daripada model $K$ Nearest Neighbor. Dalam hal ini hasil prediksi rating oleh model Matrix Factorization bisa dikatakan lebih akurat dibandingkan dengan model $K$-Nearest Neighbor. Hal ini juga dipengaruhi oleh nilai MAE dan RMSE pada model Matrix Factorization yang lebih rendah dibandingkan dengan model K-Nearest Neighbor.

\section{Kesimpulan}

Kesimpulan yang didapat setelah dilakukan pengujian dan analisis prediksi rating oleh kedua model didapat bahwa model dengan performa terbaik untuk mesin rekomendasi berbasis prediksi rating adalah Matrix Factorization dengan nilai MAE sebesar 0,6417 dan RMSE sebesar 0,8305 hasil tersebut lebih kecil dibandingkan dengan model K-Nearest Neighbor menghasilkan nilai MAE sebesar 0,6742 dan RMSE sebesar 0,8863, di mana prediksi dengan nilai MAE dan RMSE yang lebih kecil merupakan prediksi yang lebih akurat. Hal ini dibuktikan dengan hasil prediksi rating model Matrix Factorization yang mendekati nilai rating aslinya.

\section{Saran}

Disarankan dalam pengembangan penelitian selanjutnya yaitu dengan melakukan perbandingan model Matrix Factorization dan K-Nearest Neighbor dengan parameter uji yang berbeda, dibuatkan sebuah GUI agar bisa dilakukan penilaian hasil rekomendasi oleh real user dan menguji model dengan dataset yang berbeda.

\section{Referensi}

Abraham, S., \& Rahayu, Y. D. (2017). Sistem Rekomendasi Artikel Berita Menggunakan Metode K-Nearest Neighbor Berbasis Website. In Prosiding SENSEI 2017 (pp. 179-187). Jember: Universitas Muhammadiyah Jember.

Adellya, A., Devi, P., \& Tonara, D. B. (2015). Rancang Bangun Recommender System dengan Menggunakan Metode Collaborative Filtering untuk Studi Kasus Tempat Kuliner di Surabaya. JUISI Jurnal Informatika Dan Sistem Informasi, 01(02),

102-112. https://doi.org/10.1212/WNL.0b013e3181dbb664 
Alasadi, S. A., \& Bhaya, W. S. (2017). Review of Data Preprocessing Techniques. Journal of Engineering and Applied Sciences, 12(16), 41024107.

Amatriain, X., Jaimes, A., Oliver, N., \& Pujol, J. M. (2011). Recommender Systems Handbook Chapter 2 Data Mining Methods for Recommender Systems. Boston: Springer US. https://doi.org/10.1007/978-0-387-85820-3

Bokde, D. K., Girase, S., \& Mukhopadhyay, D. (2015). Matrix Factorization Model in Collaborative Filtering Algorithms: A Survey ScienceDirect Matrix Factorization Model in Collaborative Filtering Algorithms: A Survey. Procedia Computer Science, 49, 136-146. https://doi.org/10.1016/j.procs.2015.04.237

Cui, B. (2017). Design and Implementation of Movie Recommendation System Based on Knn Collaborative Filtering Algorithm. In The 4th Annual International Conference on Information Technology and Applications (ITA 2017) (Vol. 04008, pp. 8-12). Guangzhou: ITM Web Of Conforences.

https://doi.org/10.1051/itmconf/20171204008

Krishnamurty, S., Nurjanah, D., \& Rismala, R. (2017).
Sistem Rekomendasi Pada Buku Dengan Menggunakan Tags and Latent Factors. In $e$ Proceeding of Engineering (Vol. 4, pp. 46954701). Bandung: Universitas Telkom.

Li, H., Liu, Y., Qian, Y., Mamoulis, N., Tu, W., \& Cheung, D. W. (2019). HHMF: hidden hierarchical matrix factorization for recommender systems. Data Mining and Knowledge Discovery, 33(6), $1548-1582$. https://doi.org/10.1007/s10618-019-00632-4

Prasetya, C. S. D. (2017). Sistem Rekomendasi Pada ECommerce Menggunakan K-Nearest Neighbor. Jurnal Teknologi Informasi Dan Ilmu Komputer (JTIIK), 4(3), 194-200.

Sorde, R., \& Deshmukh, S. (2015). Comparative Study on Approaches of Recommendation Systems. International Journal of Computer Applications, 118(2), 753-764. https://doi.org/10.1007/978981-15-0947-6_72

Syahrani, M. A., Setiawan, E. B., \& Suryani, S. (2015). Analisis Perbandingan Sistem Rekomendasi dengan Faktorisasi Matriks dan. In SNIKTI (Seminar Nasional Ilmu Komputasi dan Teknik Informatika) (pp. 50-62). Bandung: Universitas Telkom. 